\title{
METHODS AND ANALYSIS TOOLS FOR REDEVELOPMENTS IN AN ESTUARY WITH HIGH SUSPENDED SEDIMENT CONCENTRATIONS
}

\author{
Monika Donner ${ }^{1}$, Florian Ladage, Oliver Stoschek and Hoang Ha Nguyen ${ }^{2}$
}

\begin{abstract}
One of the largest estuaries in Germany, the Ems estuary, identified a dramatic turbidity increase up to more than $10 \mathrm{~g} / \mathrm{l}$ over the last years. Due to this fact ecologists and water management authorities try to find restoration measures, which are able to reduce suspended sediment concentrations and to increase oxygen supply. The assessment of these potential restoration measures is described in the following paper and is based on a highly resolved numerical representation of the present situation of the Ems with extreme high turbidities by including effects of flocculation and hindered settling. Therefore two different approaches for the settling velocity due to flocculation were compared. An analysis of these restoration measures delivers important findings and shortcomings of each measure. Finally the restoration potentials are quantified by key indicators for hydrodynamics and suspended sediment transport behavior and were evaluated due to their relevance in reduction of high turbidities.
\end{abstract}

Keywords: high suspended sediment concentration, cohesive sediment transport, Ems estuary, restoration, releveling, lengthening

\section{INTRODUCTION}

Estuaries play an important role for ecological aspects as well as for water management and navigation channel issues. If an estuary is harmed due to extreme high turbidity, all interests are degraded. The Ems estuary, as one of the largest estuaries in Germany, indicated a dramatic turbidity increase over the last 15 years: The annual averaged suspended sediment concentration rose from $1 \mathrm{~g} / 1$ in 1992/93 (Schuttelaars \& De Jonge, 2011) up to $10 \mathrm{~g} / 1$ in 2008/09 (NLWKN Aurich, 2009) accompanied by an extreme shift of the estuarine turbidity maximum to upstream locations. This development resulted in a classification as "heavily modified" water body with "heavily polluted" water quality by EU-WFD. As a consequence dissolved oxygen is reduced during summer to zero with disastrous effects for the aquatic fauna. One central reason for the mentioned critical turbidity was induced by the deepening of the Lower Ems (Weilbeer, 2005). But also additional anthropogenic impacts resulted in hydro- and morphodynamic changes, as described based on selected examples in the following section (more details see f.e. Talke \& De Swart, 2006):

The Ems Estuary consists of the Outer, Lower and the lower section of Middle Ems, which is also tidal influenced today. The Outer Ems (Figure 1) including the Dollart describes the section from Pogum to the sea side with its polyhaline to mesohaline (brackish water) sections. In this downstream part the wadden and intertidal areas of the Dollart were reduced from 1600 to 1967 down to about $30 \%$ (Herrling \& Niemeyer, 2007). Since 1873 with enforcements from 1958 to 1961 the Geise dam was built up, which separates the water and sediment exchange between the deep-water fairway of the Ems, the so-called the Emder Fairway, and the wadden areas of the Dollard. In addition several regulation-measures were undertaken, like the reduction of the two deep-water channels to one main deep channel. During the deepening of the Outer Ems from the $30^{\mathrm{s}}$ to the $80^{\mathrm{s}}$, the riverbed was reduced from -8.0 down to $-12.5 \mathrm{~m}$ below the hydrographical datum (SKN). The Lower Ems (Figure 1) as an oligohaline brackish water section extends from Pogum about $30 \mathrm{~km}$ upstream to Papenburg and includes the storm surge barrier, which has been operating since 2001. Due to regulations and oxbows cut-offs during the last hundred years from 1898 till 2005 about $15 \%$ of the tidal river length was reduced (Herrling \& Niemeyer, 2008), which resulted in a general reduction of sub-, inter- and supratidal areas. Within 10 years from 1984 to 1994, the deepening of the Lower Ems took place with a reduction form about -2.8 and $-4 \mathrm{~m} \mathrm{NN}$ between Papenburg and Gandersum (Lange, 2006) down to $7.3 \mathrm{~m} \mathrm{NN}$ for a shipyard in Papenburg. Since then the oxygen supply was reduced from $6 \mathrm{mg} / \mathrm{l}$ down to less than $1 \mathrm{mg} / \mathrm{l}$ during summer (Lange, 2006). The Middle Ems describes the fresh water section upstream from Papenburg and includes the weir in Herbrum, which has been the tidal boundary of the estuary since 1899. Due to the increase of tidal range downstream, the weir is overtopped during high tides nowadays.

\footnotetext{
${ }^{1}$ Hydrodynamics and Coastal Engineering, DHI-WASY GmbH, Max-Planck-Straße 6, 28857 Syke, Germany: mod@dhi-wasy.de, fll@dhi-wasy.de and ost@dhi-wasy.de

2 DHI-NTU, DHI Water \& Environment Pte Ltd, 1 CleanTech Loop, \#03-05 CleanTech One, Singapore 637141, hhn@dhi.com.sg
} 


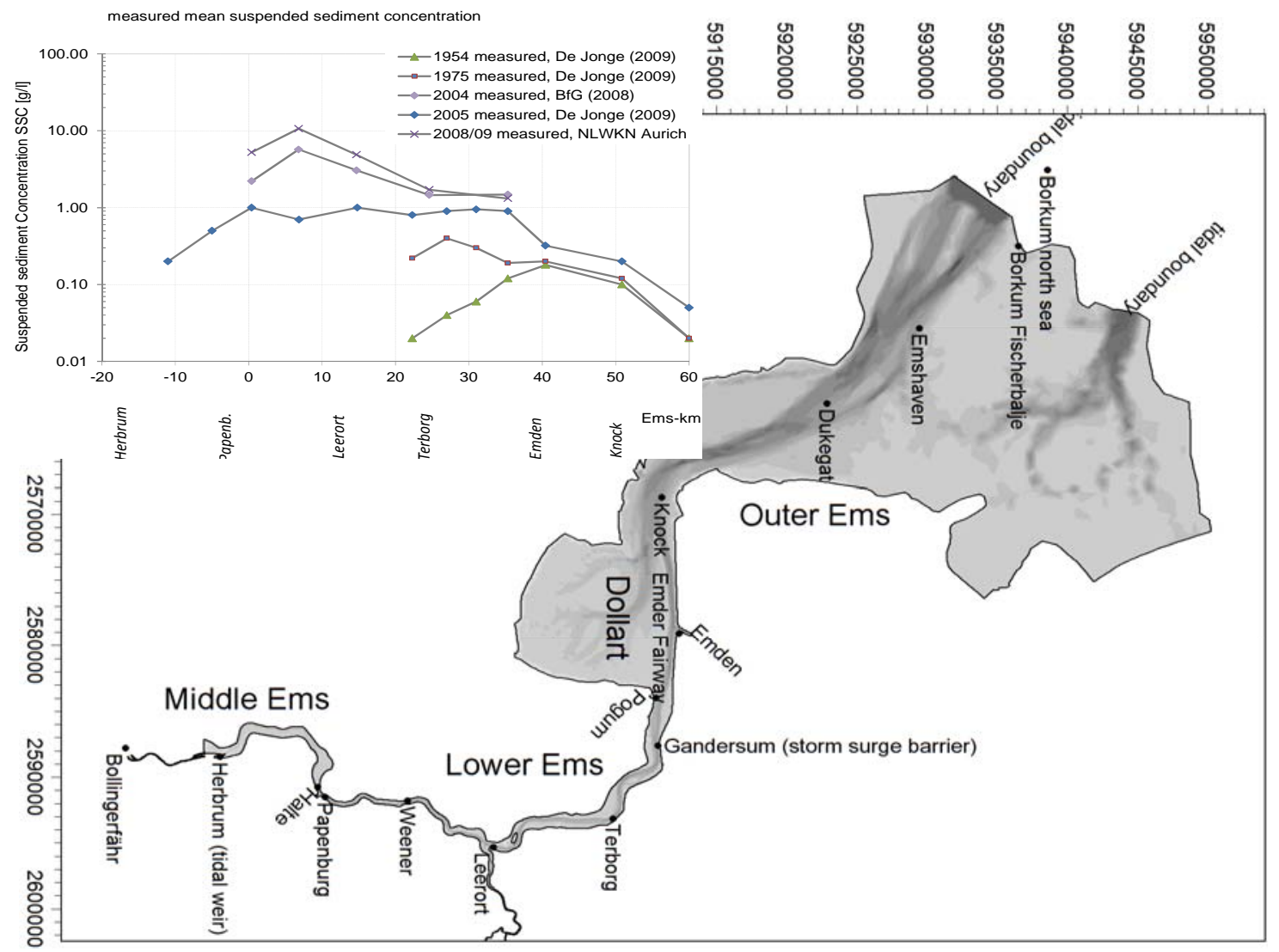

Figure 1. Ems Estuary from the sea side to the upstream section at Bollingerfähr (background) and historical evolution of measured suspended sediment concentrations measured by de Jonge (2009, in Schuttelaars \& De Jonge, 2011), BfG (2008) and NLWKN Aurich (2008/09)

These impacts are reflected in hydrodynamic changes and an increase of the suspended sediment concentration. The low tide was reduced and high tide was increased, especially due to the deepening. As consequence the tidal range especially in Herbrum increased from 1 up to $3.5 \mathrm{~m}$ during the last 70 years and the maximum range was shifted upstream to Papenburg with $3.8 \mathrm{~m}$ tidal range under low discharge today (Jürges \& Winkel, 2003). In addition the asymmetry of flood and ebb increase the flood dominance with higher flood maximum currents while ebb currents are almost constant. The gradient of the slack water to flood flow is up to 8 times steeper than, gradient of the slack water to ebb flow (Figure 3). This hyper-synchronous behavior of the tide between Emden and Papenburg, which is represented by an increasing tidal range and flood dominance, is forced by the narrowed and deepened river channel, which reduces friction and convergence (Salmon \& Allen, 1983).

The historical development of the annual averaged suspended sediment concentration (Figure 1) demonstrates that during the $50^{\mathrm{s}}$ the ETM was located in Emden with about $0.2 \mathrm{~g} / \mathrm{l}$. After deepening the Outer Ems (1975-76) the ETM was shifted upstream to Terborg with an increase up to $0.4 \mathrm{~g} / \mathrm{l}$. After the first deepening of the Lower Ems, two ETMs with about $1 \mathrm{~g} / 1$ appeared. The seasonal variation for the flood averaged suspended sediment concentration (Figure 1) near the riverbed in deep water is varying between 10 to $20 \mathrm{~g} / 1$ form May to June at Weener (according to NWLKN, 2009). Compared to the ebb averaged values for the same period, which vary between 2 to $8 \mathrm{~g} / \mathrm{l}$, the flood averaged concentration exceeds these values 3 up to 5 times. This already indicates tidal pumping in the deep channel. Especially from the mouth of the Lower Ems in the so-called Emder Fairway sediments are imported during low and mean discharge events into the Ems Estuary. These deficits in the hydro- and sediment dynamics impair the aquatic environment, but also amplify siltation, which intensifies the maintenance work in the fairway. 
Today ecologists and water management authorities working together in a joint research project called "Perspective revitalized Lower Ems" try to find solutions by restoration measures (scenarios) to damp the hydrodynamic deficits and to reduce suspended sediment, in order to increase the oxygen supply on medium term. Therefore different ideas of restoration variants were developed by water authorities, nature protection associations and international experts.

1. Retention Polders: Tidal polders are able to retain tidal volume, sediments and to reduce the tidal volume upstream. Additionally the tidal range and the hyper-synchronous character will be reduced.

2. Lateral retention: Here shallow water zones are combined with reactivated historical oxbows. Due to the separation of the water and sediment flow, especially dissipation reduces currents and consequently the dynamics.

3. Lengthening: An increased length of the Estuary by a removal of the tidal weir in Herbrum will change the tidal wave propagation and especially reduce the reflection of the tidal wave at the weir.

4. Re-leveling: The idea of an "un-deepening" stands for a re-leveling of the deep channel between Leer and Papenburg. The morphological effect due to the reduction of the width-to-depth ratio will reduce the tidal range and the tidal currents.

5. Regulation: Technical options with different regulations at the storm surge barrier near the mouth of the Ems will reduce the sediment import based on different regulations (Wurpts, 2012). These technical variants were not examined in the mentioned joint research project.

The presented paper will only focus on restoration effects of the lengthening and the re-leveling for the Ems estuary. Therefore results from existing studies especially on the lengthening were taking into account. Details for the impacts due to lateral and polder retentions are described in Donner et al., 2012.

\section{METHODOLOGY}

In order to analyze the effect of lengthening and the re-leveling variants, the present situation of the Ems Estuary with its hydrodynamics and high suspended sediment concentrations were recovered by a numerical approach, by taking two different approaches for the sediment transport into account.

\section{Numerical approaches}

The numerical analysis was realized with a three-dimensional resolution of the hydrodynamic processes, the salinity and suspended sediment transport for the Ems Estuary between Borkum (sea side) and Bollingfähr (upstream boundary). Therefore a finite volume method with a sigma layer approach in an unstructured grid (MIKE 3 FM) was used. The hydrodynamics are solved based on the RANS equation, with a density coupled to the salinity transport. For the turbulence closure a k- $\varepsilon$ approach in the vertical and the mixing length Smagorinsky approach with a coefficient of 0.28 in the horizontal direction were applied. The flow resistance effect of the almost frictionless riverbed, due to the cohesive and muddy sediments, was included based on a roughness approach according to Nikurasde with a roughness height between 0.5 and $5 \mathrm{~mm}$ in the supratidal area.

Two different methods (MT method and EL method) for the sediment dynamics were used and compared. Their main differentiator is the approach for settling velocities. The suspended sediment transport is solved for both methods with the $3 \mathrm{~d}$-advection-diffusion equation, taking hindered settling and cohesive sediment properties into account. Due to the presence and a high ratio of fine sand, silt and clay fraction, sand fractions and bed load transport play a less important role for the suspended sediment dynamics, but will gain importance for the morphological changes (Weilbeer, 2003). The erosion and deposition rates are included for both methods based on the critical shear stress approach. The erosion rate is based on the formula according to Partheniades (1965) for consolidated cohesive sediments, which is well known by:

$$
\mathrm{S}_{\text {ero }}=\beta_{\text {ero }}\left(\frac{\tau_{0}}{\tau_{\mathrm{c}, \text { ero }}}-1\right) \text { for } \tau_{0}>\tau_{\mathrm{c}, \text { ero }}
$$

where $\beta_{\text {ero }}$ is the erodibility factor $\left[\mathrm{g} / \mathrm{m}^{2} / \mathrm{s}\right], \tau_{c, \text { ero }}$ the critical erosion shear stress $\left[\mathrm{N} / \mathrm{m}^{2}\right], S_{\text {ero }}$ the Erosion rate $\left[\mathrm{g} / \mathrm{m}^{2} / \mathrm{s}\right]$, and $\tau_{0}$ the bed shear stress $\left[\mathrm{N} / \mathrm{m}^{2}\right]$. For both methods the general empirical erosion and deposition parameters were narrowed based on empirical approaches, literature values and grain size distributions for the Ems, which were provided by the BAW and the NLWKN. The dry bulk density of the bed material was estimated based on an empirical approach according to Allersma (1988 
in Van Rijn, 2007), which resulted in an interval of 170 to $1290 \mathrm{~kg} / \mathrm{m}^{3}$ for the dry bulk density. The critical erosion shear stress was limited based on an approach according to Zanke (1982) for soft and unconsolidated mud between 0.12 and $0.45 \mathrm{~N} / \mathrm{m}^{2}$. The erodibility factor was estimated based on the approach according to Schweim (2005) taking the varying range of literature values from 0.01 up to $5 \mathrm{~g} / \mathrm{m}^{2} / \mathrm{s}$ into account.

The deposition rate $\mathrm{D}$ is described according to Krone (1962) by:

$$
\mathrm{D}=\mathrm{w}_{\mathrm{s}} \cdot \mathrm{c} \cdot\left(1-\frac{\tau_{0}}{\tau_{\mathrm{c}, \text { dep }}}\right) \text { for } \tau_{0} \leq \tau_{\mathrm{c}, \text { dep }}
$$

where $\mathrm{w}_{\mathrm{s}}$ is the settling velocity $[\mathrm{m} / \mathrm{s}], \mathrm{c}_{\mathrm{b}}$ the near-bed concentration $\left[\mathrm{g} / \mathrm{m}^{3}\right], \tau_{c, \text { dep }}$ the critical shear stress for deposition $\left[\mathrm{N} / \mathrm{m}^{2}\right], D$ the deposition rate $\left[\mathrm{g} / \mathrm{m}^{2} / \mathrm{s}\right]$, and $\tau_{0}$ the bed shear stress $\left[\mathrm{N} / \mathrm{m}^{2}\right]$. The critical shear stress for deposition values are given by Partheniades (1965) with 0.04 up to $0.15 \mathrm{~N} / \mathrm{m}^{2}$ and by Li et al. (1994) with 0.3 up to $0.5 \mathrm{~N} / \mathrm{m}^{2}$. For the Ems a constant value of $0.07 \mathrm{~N} / \mathrm{m}^{2}$ was applied.

For the MT method the settling velocities were based on an empirical flocculation approach according to Burt (1986) and a hindered settling for $\mathrm{c}>\mathrm{c}_{\text {hinder }}$ approach according to Winterwerp (1999):

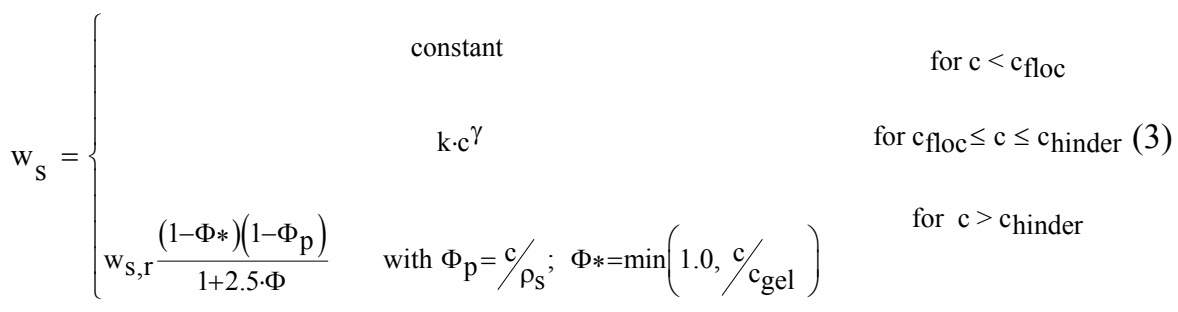

where $\mathrm{w}_{\mathrm{s}}$ is the settling velocity $[\mathrm{m} / \mathrm{s}], \mathrm{k}$ and $\gamma$ are coefficients [-], $\mathrm{c}_{\text {floc }}$ is the threshold concentration for the flocculation $\left[\mathrm{kg} / \mathrm{m}^{3}\right], \mathrm{c}_{\text {hinder }}$ is the threshold concentration for the hindered settling $\left[\mathrm{kg} / \mathrm{m}^{3}\right], \mathrm{w}_{\mathrm{s}, \mathrm{r}}$ is the reference settling velocity $[\mathrm{m} / \mathrm{s}], c_{\text {gel }}$ is the threshold concentration for the gelling point $\left[\mathrm{kg} / \mathrm{m}^{3}\right], \rho_{\mathrm{s}}$ is the sediment density $\left[\mathrm{kg} / \mathrm{m}^{3}\right]$.

In the alternative EL method a new approach for the flocculation developed by Nguyen (2010, 2012) was applied and compared to the MT method. This method is based on the same description and solution of the hydrodynamic as described above (MIKE 3 FM). Also the sediment transport (3d advection-diffusion), as well as erosion and deposition rates are computed analogous based on the approaches by Partheniades (1965) and Krone (1962). The difference is given by the settling velocity, which is taking the floc size, floc density and drag coefficient into account under consideration of effects caused by salinity and turbulence; the computation of the settling velocity is based on the modified Stokes law:

$$
\mathrm{w}_{\mathrm{S}}=(1-\phi) \sqrt{\frac{4 \cdot\left(\rho_{\mathrm{f}}-\rho_{\mathrm{m}}\right) \cdot \mathrm{g} \cdot \mathrm{D}_{\mathrm{f}}}{3 \cdot \rho_{\mathrm{m}} \cdot \mathrm{C}_{\mathrm{D}, \mathrm{mt}}}}
$$

where $\mathrm{w}_{\mathrm{s}}$ is the settling velocity under turbulence $[\mathrm{m} / \mathrm{s}], \phi$ the volumetric concentration of flocs in the mixture $\left[\mathrm{m}^{3} / \mathrm{m}^{3}\right], \rho_{\mathrm{f}}$ the floc density $\left[\mathrm{kg} / \mathrm{m}^{3}\right], \rho_{\mathrm{m}}$ the density of sediment-fluid mixture $\left[\mathrm{kg} / \mathrm{m}^{3}\right], D_{\mathrm{f}}$ is the floc size $[\mathrm{m}]$, and $\mathrm{C}_{\mathrm{D}, \mathrm{mt}}$ the drag coefficient of flocs [-]. The floc size is computed as a result of aggregation and breakup processes. So an increase of suspended sediment concentration leads to a higher probability of primary particle collisions, which is encouraging aggregation. High salinity is considered to support the formation of flocs as well by compression of the electric double layer of the particles and for this reason growing effect of van-der-Waals force. High turbulence will cause a breakup of flocs. Based on the floc size, the floc density is calculated subsequently. The drag coefficient depends on the shape and size of the primary particles or flocs and furthermore on the viscosity of the sediment-fluid mixture. Consideration of turbulence in the calculation of floc size and drag coefficient can be regarded to be a unique characteristic of the approach implemented in EL method.

\section{Calibration and Approach comparison}

The numerical model of the Ems was calibrated and validated against measured time series for water levels, currents, salinity and suspended sediment concentrations (Figure 2). Three summer events 
in 2008 with a low fluvial discharge (ca. $40 \mathrm{~m}^{3} / \mathrm{s}$ ), a mean discharge (ca. $80 \mathrm{~m}^{3} / \mathrm{s}$ ) and an annual mean flood discharge (ca. $110 \mathrm{~m}^{3} / \mathrm{s}$ ) were regarded. Winter events and storm surges are not significant conditions for the high turbidity in the Ems. For quantifying the model performance the mean error (ME) was used. For water level and the tidal currents the ME was good with less than $0.12 \mathrm{~m}$ for the water level $(0.05$ to $0.24 \mathrm{~m})$ and about $0.14 \mathrm{~m} / \mathrm{s}$ for the currents $(0.07$ to $0.22 \mathrm{~m} / \mathrm{s})$. A delay appears in the phase between the simulated and measured tidal curve. The amplitude of the high tide is reproduced with variations below $10 \mathrm{~cm}$ (mean value) quite well, while the amplitude of the low tide is slightly overestimated with a up to about $20 \mathrm{~cm}$ (mean value). Based on 30 PSU at the sea side and for low fluvial discharges (MHQ to $40 \mathrm{~m}^{3} / \mathrm{s}$ ), which are the relevant conditions for the high suspended sediment concentrations in the Ems, the measured salinity condition between Knock and Herbrum were represented in the numerical model with a mean error of 3.1 down to less than 0.01 PSU.

Due to the calibration of sediment transport the above described empirical parameters result in critical erosion shear stresses of 0.20 to $0.28 \mathrm{~N} / \mathrm{m}^{2}$ for the Outer Ems and 0.11 to $0.18 \mathrm{~N} / \mathrm{m}^{2}$ for the Lower Ems, erodibility factor for the Outer Ems with 0.01 to $0.015 \mathrm{~g} / \mathrm{m}^{2} / \mathrm{s}$ and the Lower Ems with 0.02 to $0.10 \mathrm{~g} / \mathrm{m}^{2} / \mathrm{s}$ and a constant dry bulk density of $300 \mathrm{~kg} / \mathrm{m}^{3}$. The suspended sediment concentration results in good accuracy with a difference between measured and simulated suspended sediment concentrations of 0.2 up to $3.9 \mathrm{~g} / 1$ (for MT method) and 0.3 up to $3.7 \mathrm{~g} / 1$ (for EL method). The high delta of more than $3 \mathrm{~g} / \mathrm{l}$ is for both methods generated by an underestimation of a local suspended concentration peak in the measured time series. Herein the measured time series of the suspended sediment concentration in- and decreases during slack water at the low tide from $5 \mathrm{~g} / \mathrm{l}$ up to $40 \mathrm{~g} / \mathrm{l}$ with a gradient of $\pm 7.8 \mathrm{~g} / \mathrm{l} / \mathrm{min}$ near Weener and $\pm 3.7 \mathrm{~g} / \mathrm{l} / \mathrm{min}$ near Papenburg. Both measurement positions are located about $3 \mathrm{~m}$ above the river bed.
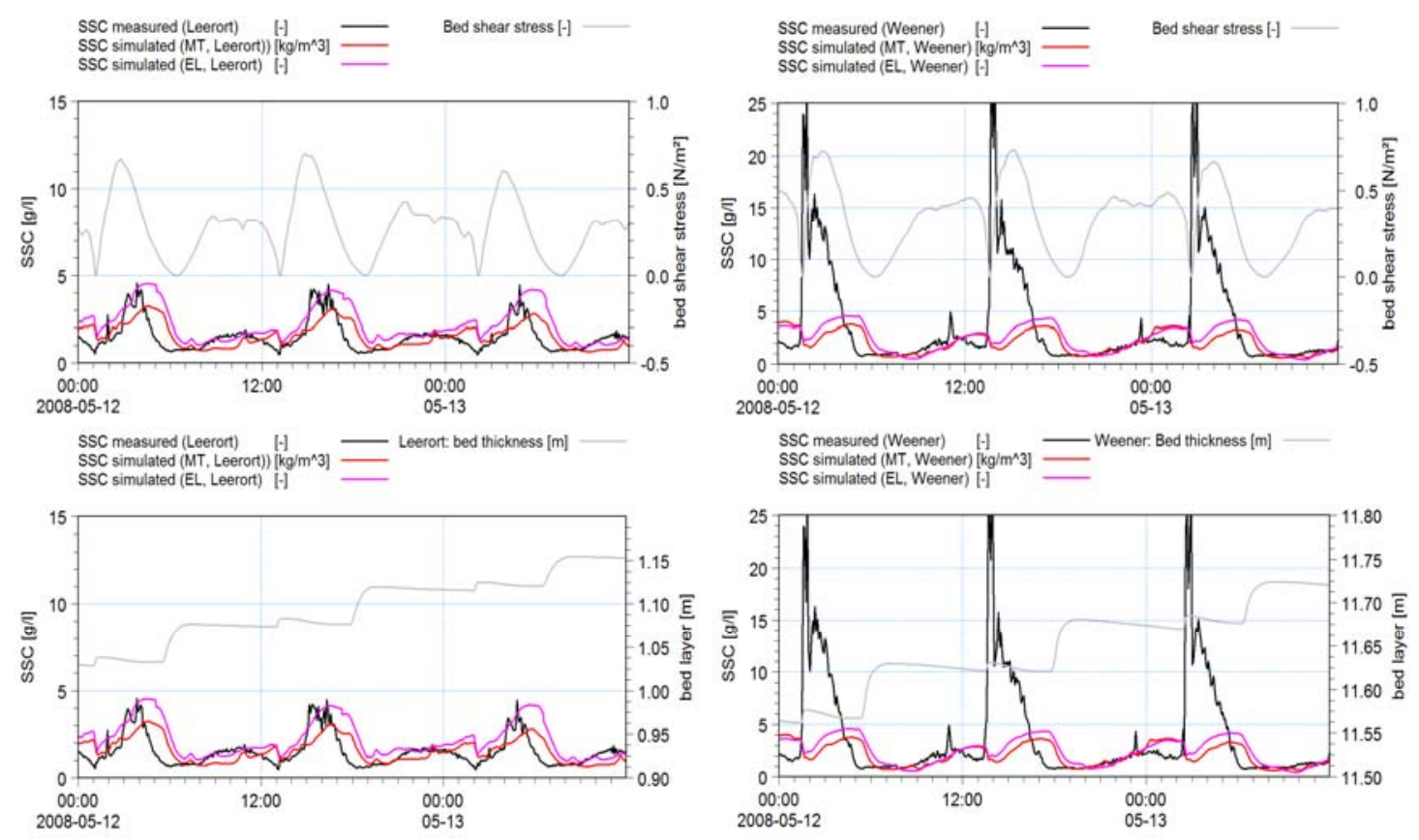

Figure 2. Comparison of simulated and measured time series in 2008 for suspended sediment concentrations at the Station in Leerort (Ems-km 14, left) and in Weener (Ems-km 7, right) in comparison with the simulated bed shear stress and the bed layer thickness, the measured data was provided by NWLKN Aurich (SSC)

This peak concentration is only approximately resolved by the numerical model with significant lower amplitude. There might be three reasons for these temporary peak concentrations under minimal flow velocities near slack water:

- Suspended sediments are settling in the water column during slack water and due to hindered settling a very high concentrated near bed layer with an increasing thickness appears

- With the incoming flood flow very high concentrated near bed layer (fluid mud) is moved upstream and is accumulated between Weener and Papenburg.

- Suspended near bed sediments are re-suspended into the water column due to the high velocity gradient after slack water. 
Apart from the concentration peaks upstream the tidal oscillation of the SSC is recovered by the numerical model (Figure 2).

The comparison between the two methods for the settling velocity showed, that the refined EL method is able to represent slightly higher suspended sediment concentrations especially during flood flow (see sharp peak in bed shear stress on the right side in figure 2). But both methods are not able to refigure the sharp increase and decrease of the suspended sediment concentration. The reason for can be found in the shear stress based erosion and deposition rate, which is used for both. Based on this approach the high concentrated suspension can only be refigured in the soft bed layer increase (here with a density of $360 \mathrm{~kg} / \mathrm{m}^{3}$ ). The reaction of the bed layer is represented immediately. The growth of the soft bed layer in both upstream locations is representative for the aggregation of fine soft sediment at the river bed. The morphological feedback due to this growth was not included.

\section{Assessment of the restoration potentials}

For the assessment of the restoration variants so-called key indicators like flood dominance or the net sediment transport were selected, which are representative for fine sediments and high suspended sediment concentrations. Therefore indicators for flood dominance, tidal asymmetries, tidal range and sediment import where categorized based on their importance on fine sediment transport. The ranking of the indictors is based on the experience of different analyses as well as existing literature (e.g. Lang, 2003).

One of the most important hydrodynamic indicators is the reduction of flood flow, which specifies a reduction of sediment import. The longitudinal section of the maximum gradient ratio between flood and ebb currents represents a rough pointer for position of the ETM in the longitudinal section, with high ratios near the ETM. A reduction of the ratio of maximum currents (flood dominance) and an additional reduction in tidal range, especially a decrease in the upstream raise of both parameters, represent a damping of the hyper-synchronous character. Existing research studies (e.g. Hoitink et al. (2003), Van de Kreeke (1996)) revealed a rough connection between the net sediment transport and the ratio of M4/M2 amplitude, as key indicator for tidal asymmetry. Tidal asymmetry increases if the M2-amplitude is high compared to the flow resistance due to friction and morphology, which is captured by the M4-amplitude. If the M2 amplitude is reduced compared to the M4-amplitude, both effects are damping the tidal asymmetry (Speer et al., 1985).

The hydrodynamic key indicators for a restoration assessment are:

- Reduction of tidal asymmetry based on the net flow ratio below 1 , which is describing the ratio between flood flow/ (ebb flow - fluvial inflow). This includes a decrease of flood flow as indicator for reduction of flood flow induced sediment transport and an increase of ebb flow.

- Reduction of the ratio of maximum gradient between flood /ebb currents $(\mathrm{dv} / \mathrm{dt})$ in the main channel, which is an indicator for fine sediment transport acc. to Dronkers (1986) and is relevant for the duration and intensity of re-suspension or sedimentation near slack water.

- Reduction of the flood dominance based on the ratio of maximum flood/ ebb currents in the main channel below 1 (flood dominance with a ratio $>1$ ), which is also representing the hypersynchronous character of the Estuary and is an indicator for coarse sediment transport acc. to Dronkers (1986).

- Increase of the low tide as general indicator for an effect on the hydrodynamic behavior, which is resulting in a reduction of maximum flood currents and in an increase of maximum ebb currents.

- Decrease of tidal range by avoiding an increase of the tidal range from the mouth to upstream sections (hyper-synchronous character), which a general indicator for an effect on the hydrodynamic behavior

- Increase of the M4/M2 amplitudes ratio with an increase of M4-amplitude and a decrease of the M2 Amplitude as a rough indicator for a change of the sediment transport behavior

The restoration effect is evaluated based on sediment transport behavior, due to a change of the net sediment transport near the mouth and a shift of the ETM. An annual averaged sediment export at the mouth extended to upstream sections will reduce the suspended sediment concentration on larger time scales in the Lower Ems. Therefore a turn from sediment import to sediment export in the Emder Fairway (which is corresponding with the mouth of Lower Ems) is an essential change. Due to the export of fine suspended sediment an accumulation of fine sediments in the fairway can be reduced and enables a change of the grain size distribution in the main channel. On the other hand local sediment import zones in upstream sections are regarded as less critical for the overall situation. In addition a reduction of the cross-sectional integrated and tidal averaged suspended sediment 
concentration with a downstream-shift of the ETM should be achieved. This shift indicates a lower sediment transport in the water column and consequently a lower mobilization or re-suspension of sediment due to reduced tidal dynamics. The downstream shift is consequently an indicator of a change to lower turbidities.

Sediment key indicator for a for a restoration assessment of estuaries with fine sediments are:

- Decrease of net sediment import, with a turn to sediment export near the mouth to upstream sections based on a cross-sectional and tidal integrated sediment transport

- Downstream shift and reduction of the ETM based on a mean suspended sediment concentration by a cross-sectional and tidal averaged suspended sediment concentration

- Decrease of cross-sectional and tidal averaged suspended sediment concentration below a critical threshold according to ecologists with $100 \mathrm{mg} / \mathrm{l}$ for the fresh water section

\section{CONDITIONS FOR THE ASSESSMENT}

The numerical and assessment methods were used to analyze the effect of the re-leveling and lengthening. The mentioned key-indicators were compared to the present situation based on a shortterm analysis over about two neap-spring-cycles for the following scenarios:

- Scenario A1 includes a decrease of the water depth between Ems-km 14 up to 0 (Leer to Papenburg) form about -8 to $-5 \mathrm{~m} \mathrm{NN}$ to a constant bed level shift on $-3.0 \mathrm{~m} \mathrm{NN}$ (re-leveling). Here two sub-scenarios with the present sediments and with a sandy bed at the re-leveling were compared

- Scenario A2 includes decrease of the water depth between Ems-km 14 up to 0 as described in Scenario A1 in combination with three polders upstream, two at Ems-km -2.5 with 500 ha and 250 ha and one polder at Ems-km -7 with 250 ha. All tidal polders are able to store a volume of about 29 million $\mathrm{m}^{3}$. Here also two sub-scenarios with the present sediments and with a sandy bed at the re-leveling were compared

- Scenario B describes a lengthened Ems Estuary, with a removal of the weir in Herbrum and a combination of two downstream polders, one at Ems-km 24 with 200 ha and Ems-km 12 with 400 ha. Both tidal polders are able to store a volume of about 18 million $\mathrm{m}^{3}$.

The idea behind the reduction of the water depth is an artificial return to historical bed levels of the Lower Ems before the deepening took place. Due to a lower water depth the low tide, tidal range and the tidal expanse to upstream will decrease. Both scenarios A1 (re-leveling) and A2 (re-leveling with upstream polders) would require an artificial channel between Ems-km 14 and 0 (Papenburg to Leer) for navigation. This potential new channel was not included into the analysis of the restoration potential, due to its negotiable relevant on the tidal and sediment dynamics in the Ems estuary. Due to the navigation channel requirements downstream of Ems-km 14 (Leer) the existing river bed level is required, which results in a bed slope between the navigation channel depth downstream and the releveling section. In addition upstream of Papenburg the navigation depth for the main channel is necessary. These conditions result in a longitudinal section with a plateau between Ems-km 14 and 0. For the re-leveling two sediment conditions at this plateau were assumed: one with the actual grain size distributions (silty bed) and one with a changed grain size to sand fractions (sandy bed), which assumes at best case a revitalized Ems at the re-leveling. For the sandy bed a roughness height of $0.01 \mathrm{~m}$ was assumed. Additional the sediment parameters were changed with an increase of the critical erosion shear stress form 0.14 to $0.125 \mathrm{~N} / \mathrm{m}^{2}$ (silty bed) to $0.22 \mathrm{~N} / \mathrm{m}^{2}$ (sandy bed). The erodibility factor was reduced from 0.07 to $0.05 \mathrm{~g} / \mathrm{m}^{2} / \mathrm{s}$ (silty bed) down to $0.025 \mathrm{~g} / \mathrm{m}^{2} / \mathrm{s}$ (sandy bed).

The effect of lengthening was developed and analyzed in detail by Schuttelaars \& De Jonge (2011). They proved based on an analytical 1d-approach, which is simplifying the detailed geomorphology, but is taking the tidal propagation and cohesive sediment transport into account, that the location of the tidal weir has an effect on the location of the estuarine turbidity maximum. The most important outcomes of their study were: For the actual bed level (here 2005) including the weir at Herbrum the Ems estuary has a length that is close to the M2-tide resonance length, so the tidal wave has a standing wave character. Due to an upstream lengthening by a shift of the weir, the model predicted an ETM shift from Leer and Papenburg for the actual length down to Emden for about more than 10 kilometer lengthening. A similar but less significant effect was represented by a detailed numerical 3d-analysis for the Ems estuary of the BAW (Rollenhagen, 2011), which regarded a crest reduction of the weir in Herbrum from $+1.8 \mathrm{~m} \mathrm{NN}$ down to $-0.5 \mathrm{~m} \mathrm{NN}$. This reduction of the weir height resulted in slight downstream reduction of the tidal averaged suspended sediment concentration and a very small shift of the ETM. Based on these experiences the lengthening was regarded in 
Scenario B with a full removal of the weir in Herbrum down to the bed level of about $-1.5 \mathrm{~m} \mathrm{NN}$ and was combined with two downstream polders in order to enhance the effect of ETM reduction and to reduce the tidal range by additional measures.

All scenarios A1, A2 and B were simulated based on the outlined numerical approaches for hydrodynamics, salinity and sediment transport by including the relevant restoration element. Therefore a short-term period with measured tidal cycles from May 2008 at Borkum over about 3.5 weeks (MLW +1.27 m NN, MHW $-1.97 \mathrm{~m} \mathrm{NN}$, tidal range $3.25 \mathrm{~m}$ at Knock) and a constant fluvial discharge of $88.11 \mathrm{~m}^{3} / \mathrm{s}(\mathrm{MQ})$ at the upstream boundary (in Bollingerfähr) was regarded. For the suspended sediment concentration and salinity $30 \mathrm{PSU}$ and $0.02 \mathrm{~g} / 1$ were defined at the sea side and $0.34 \mathrm{PSU}$ and $0.05 \mathrm{~g} / 1$ were set at the upstream boundary.

\section{RESULTS AND DISCUSSION}

\section{Effects on tidal dynamic}

The hydrodynamics showed quite different effects for these three scenarios: The re-leveling (A1 and A2) with its reduction of the water depth due to the rise of the bed level of about $2.3 \mathrm{~m}$ (mean value) in the main channel represented negative effect downstream of the re-leveling (Ems-km 14) and a positive effects at the re-leveling section and upstream. The negative effects downstream are represented by a slight increase of the tidal range with a few centimeters, a reduction of the low tide and an increase of the high tide (Figure 3). Additionally the maximum flood currents rose, while maximum ebb currents were reduced, which results in an increase of the flood dominance downstream of the re-leveling. Also an increase of the tidal asymmetry was conducted, due to the increase of the maximum flood currents and the decrease of the mean flood currents. At the re-leveling and in upstream section the tidal range is reduced up to $1.4 \mathrm{~m} \mathrm{(A1)}$ and $2.8 \mathrm{~m} \mathrm{(A2)}$, the mean high tide up is reduced by up to $0.1 \mathrm{~m}(\mathrm{~A} 1)$ and $0.7 \mathrm{~m}(\mathrm{~A} 2)$, and the mean low tide up is increasing up to $1.3 \mathrm{~m}$ (A1) and $2.1 \mathrm{~m}$ (A2). The lengthening (scenario B) showed an overall improvement for tidal water levels with a continuous reduction of the mean tidal range up to $1.1 \mathrm{~m}$, a reduction in the mean high tide up to $0.3 \mathrm{~m}(\mathrm{C} 1)$, and a rise of the mean low tide up to $0.8 \mathrm{~m}$. The maximum tidal range in the longitudinal section with about $3.5 \mathrm{~m}$ (present situation) is slightly reduced to about $3.4 \mathrm{~m}$ and position of the maximum between Ems-km 10 to 40 is shifted downstream to Ems-km 40.

For all scenarios, for B over the whole Ems estuary, for A1 and A2 only upstream and on the re-leveling), the tidal currents were reduced. The flood dominance based on the ratio of maximum flood to ebb currents is reduced by up to $20 \%$ (A1), $45 \%$ (A2) and $60 \%$ (B) between Ems-km 15 and -5. The local maximum of the flood dominance is decreasing from a flood-dominance ratio of 1.3 (present situation, Figure 3) down to a slight ebb-dominance with about 0.9 (B, Figure 3), but is not shifted downstream. For scenario A1 and A2 the local maximum is shifted about $15 \mathrm{~km}$ downstream, but still remains flood dominant with 1.0 to 1.2 near Ems-km 30. The ratio of the maximum flood to ebb gradients, which has is maximum with 8.0 for the present situation near Papenburg (Ems-km 0 , Figure 3), is shifted downstream to Ems-km 20 to 25 under all scenarios. The reduction of the ratio due to the scenarios reaches 4.5 for $\mathrm{A} 1$ and $\mathrm{A} 2$, and 2.5 for $\mathrm{B}$.

One important effect was represented by the net balance of flood/ ebb flow without fluvial discharge (here MQ) as a ratio for the tide-driven volume flow. The net flow ratio, which represents a peak value of factor 2.0 near Ems-km 0 (Papenburg) was shifted downstream with about $5 \mathrm{~km}$ by A1 and A2 but only a slight reduction to 1.6 (A1) and 1.3 (A2). For both scenarios the peak value is significantly over the threshold of 1 . For B no downstream shift appears, but the peak value is reduced to about 1 (Figure 3).

Form the hydrodynamic side, the scenarios A1 and A2 showed shortcomings downstream, while the effects on tidal range and tidal currents were distinct in at the re-leveling and in upstream section. The main reason for the above mentioned negative impacts for scenario A1 and A2 is the sharp increase in the bed level at the re-leveling, which is comparable to a fixed ground sill. So the tidal wave is reflected and tidal asymmetry is increasing in this downstream section. Upstream of the re-leveling, backwater effects with long-lasting reduced currents and significant reduced tidal water level oscillation appears. The rising low tide is induced by the elevation of the bed level and a reduction of the wetted area in the re-leveling section. This is also displayed by a reduction of the flood volume and ebb volume flow. 


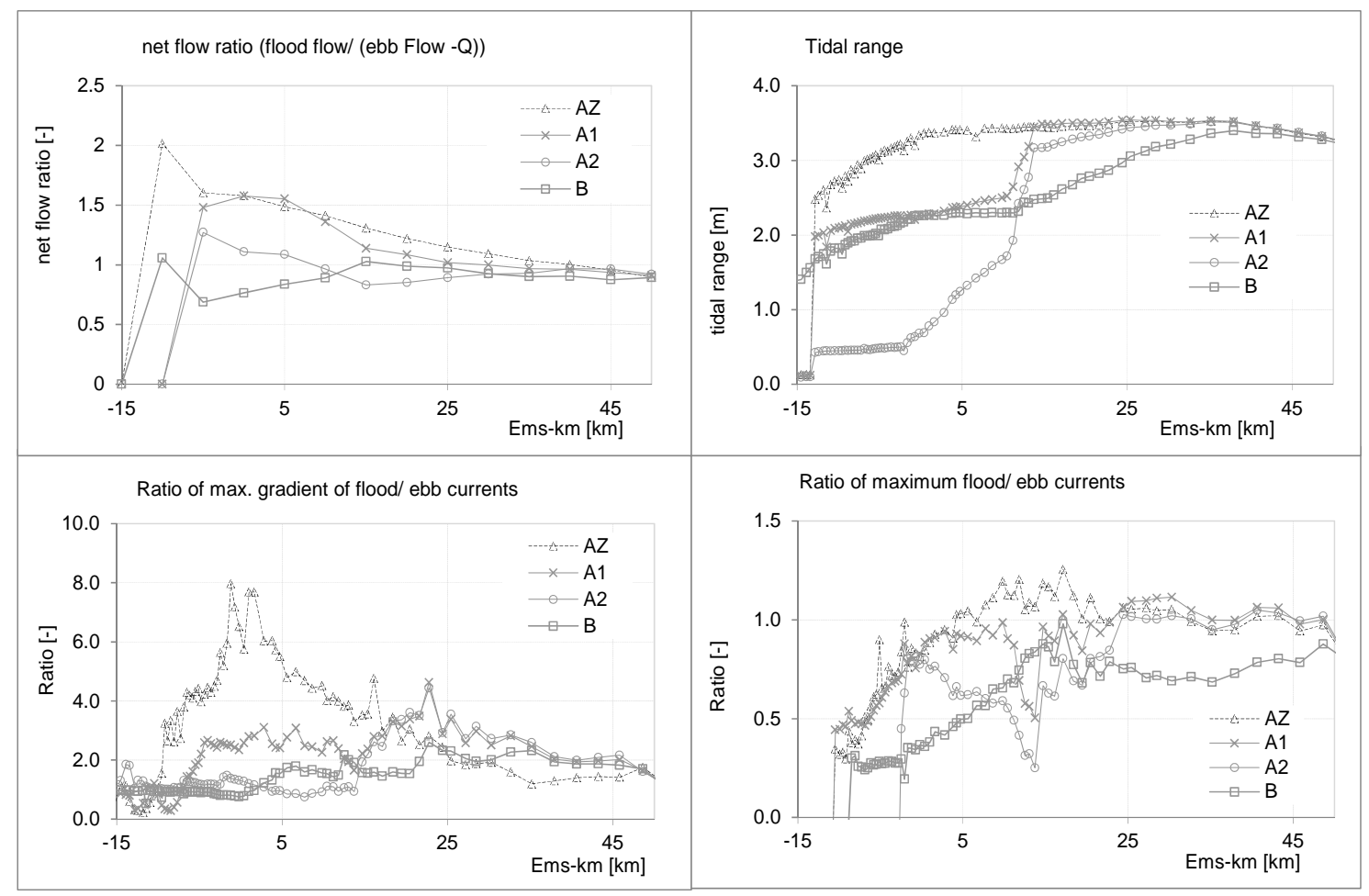

Figure 3. Longitudinal sections for the hydrodynamic key indicators net ratio of flow (top left), tidal range (top right), and ratio of maximum gradients (bottom left) and ratio of maximum flood/ ebb currents (bottom right) for the present situation (AZ), for the scenario $A 1, A 2$ and $B$

\section{Effects on the sediment transport}

For the sediment transport, indicators like net sediment flux, a shift of the estuary turbidity maximum and suspended sediment concentration were taken into account. The tidal averaged and cross-sectional integrated suspended sediment concentration (SSC) represented three zones for each scenario.

For A1 and A2 these zones are located downstream, upstream and inside the re-leveling section (Ems-km 14 to 0). For the hydrodynamics the different sediments at the re-leveling (A1 and A2), silty sediments (like in the present situation as a worst case scenario, A1 and A2) and sandy sediments (as a best case scenario A1s and A2s), had only slight effects. For the sediment dynamics the type of sediment inventory at the bottom play an important role. For the silty river bed the lower zone is located between Ems-km 15 and Ems-km 50 with a slight reduction in the SSC, a slight reduction of sediment import, but a lengthening of the import zone to upstream. In the middle zone at the releveling higher SSC with a strong sediment export between Ems-km 15 to 0 and for the upstream zone a significant reduction of the SSC under sediment import appeared. The estuary turbidity maximum is shifted downstream from Ems-km -5 to Ems-km 15 with a strong increase from $3.2 \mathrm{~g} / 1$ up to $4.5 \mathrm{~g} / 1$ (A1) and $4.5 \mathrm{~g} / \mathrm{l}$ (A2). For a sandy bed at the re-leveling the import and export characteristics is the same, also the estuary turbidity maximum is shifted downstream from Ems-km -5 to Ems-km 15, but with a decrease from $3.2 \mathrm{~g} / 1$ up to $2.4 \mathrm{~g} / 1$ (A1s) and $2.1 \mathrm{~g} / 1$ (A2s). Additionally the natural water depth is higher than the proposed one. Therefore the re-leveling will be eroded and causes extra turbidity.

For the lengthening (B, Figure 4) the lower zone turned to a sediment export but showed a slightly increased SSC, the central zone between Ems-km 15 and 0 indicated a reduced export tendency with an significant reduction in the SSC. In the upper zone with an increase of the SSC under sediment import takes place. The suspended sediment concentration (ETM) is only slightly reduced from 3.2 to $2.5 \mathrm{~g} / \mathrm{l}$, but the ETM is shifted upstream by $5 \mathrm{~km}$. Consequently the lengthening had a positive effect on the relevant sediment export over the Emder Fairway. The upstream shift of the ETM reveals two effects: the increase of tidal influence, which is already display in the hydrodynamic behavior, but also the mobilization of sediments upstream of the former weir at Ems-km -15. Due to the removal of the weir the water level is tidal influence with a range of about $1.5 \mathrm{~m}$ (see Figure 3). Consequently upstream of former the tidal weir currents are increasing from former reduced backwater 
currents to ebb-dominant currents. Upstream of the removed weir (Ems-km -15 to -20) only tidal water levels, but no flood currents (upstream velocities) appear anymore, so sediment is mobilized especially during low tide with reduced water depth of about $-2 \mathrm{~m}$ during low tide and the higher currents with an increase of to about $200 \%$. These processes are increasing sediment concentration up to $0.9 \mathrm{~g} / \mathrm{l}$ upstream of Ems-km -15 due to a short term mobilization of fine sediments there.
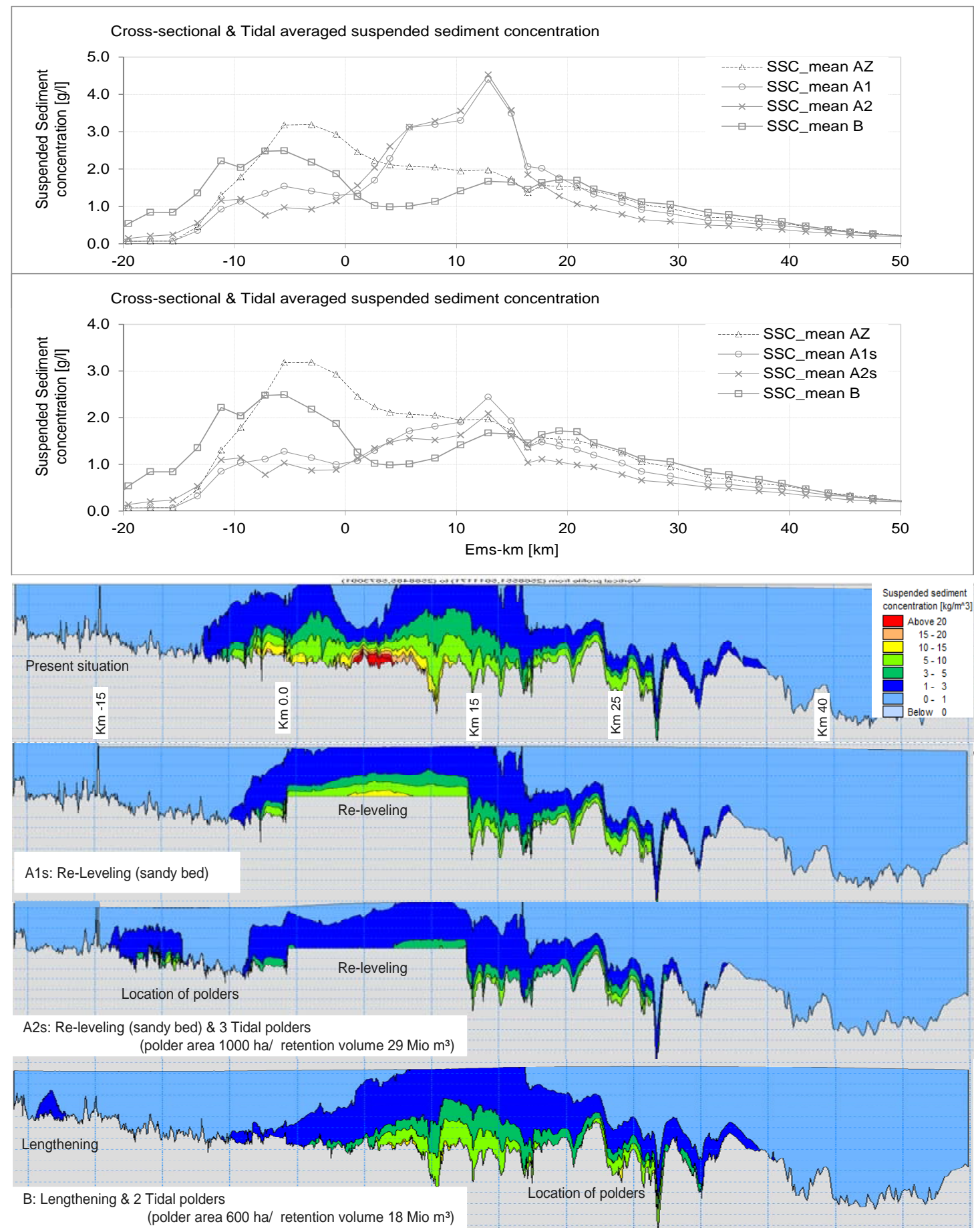

Figure 4. Longitudinal sections of cross-sectional averaged and tidal integrated suspended sediment concentration (top and second figure) and $2 \mathrm{~d}$-longitudinal sections of suspended sediment concentration in the river axis during high tide for the present situation (third figure), for the re-leveling with a sandy bed (A1s, 4th figure), for the re-leveling with a sandy bed and three tidal polders (A2s, 5th figure) and for the lengthening with a silty bed and two tidal polders (B, bottom). 
The re-leveling scenarios based on the actual sediment characteristics demonstrated negative impacts on the sediment transport and with their increase of the estuarine turbidity maximum. The increase of the length of downstream net sediment import over the mouth of the Ems indicates a medium-term worsening of the situation in the Ems, which fit together with the negative effect on the hydrodynamics in this section with an increasing flood dominance, tidal range and tidal asymmetry. The high turbidities at the re-leveling are forced additionally by the discontinuity between the releveling and the downstream navigation section. Only the downstream shift of the ETM is evaluated as a positive effect, which is representative for an improvement of the situation at the re-leveling and in upstream section. For the sandy bed a reduction of the ETM but a comparable behavior of sediment dynamics including the same net sediment import and export zones were revealed.

\section{CONCLUSIONS AND OUTLOOK}

The main reason for the above mentioned negative impacts on the hydrodynamics and sediment transport for scenario A1 and A2 is the increase in the bed level (re-leveling), which is acting like a fixed ground sill. Due to this change a discontinuity appears in the hydrodynamics as well as in the sediment dynamics. A simplified analysis of morphological stability of the re-leveling showed, that erosion of this ground sill will take place. Of course this horizontal re-leveling will turn to a sloped shape. For all scenarios A1 and A2 the positive effect on hydrodynamics are increasing and sediment concentration is strongly reduced due to the sandy river bed at the re-leveling. The tidal polders upstream had a damping effect on the shortcoming of the re-leveling.

For the restoration potential of scenario A1 and A2 on sandy bed the $14 \mathrm{~km}$ flow section, which morphology can be develop without further maintenances work, provide an additional restoration potential for sediment trapping in this section. Due to the assumed sandy sediments at the river bed the ETM was reduced and shifted downstream with about $17 \mathrm{~km}$, while the net sediment transport near the mouth is only slightly reduced, but lengthened to upstream sections. This import zone is evaluated as a strong negative impact for both scenarios, which stands for an on-going fine sediment import over the moth and worsening of turbidity and no changes in the sediment characteristic under assumed maintenance (preservation of the existing morphology) downstream of the re-leveling. Together is the restoration potential and free development of the Ems at the re-leveling section the restoration potential of both scenarios resulted in low to moderate, keeping the above mentioned shortcomings in mind.

\begin{tabular}{|c|c|c|c|}
\hline Key indicator & $\begin{array}{l}\text { Scenario A1s } \\
\text { (re-leveling with } \\
\text { sandy bed) }\end{array}$ & $\begin{array}{l}\text { Scenario A2s } \\
\text { (re-leveling with sandy bed } \\
\text { \& tidal polders) }\end{array}$ & $\begin{array}{l}\text { Scenario B } \\
\text { (lengthening \& tidal } \\
\text { polders) }\end{array}$ \\
\hline $\begin{array}{l}\text { Potential for a morphological } \\
\text { development: area and section }\end{array}$ & $\begin{array}{l}\text { re-leveling over } 14 \\
\text { flow-km }\end{array}$ & $\begin{array}{l}\text { Polder areas of } \\
1.000 \text { ha, re-leveling over } \\
14 \text { flow-km }\end{array}$ & $\begin{array}{l}\text { Polder areas area } \\
600 \mathrm{ha} \text {, Lengthening over } 9 \\
\text { flow } \mathrm{km}\end{array}$ \\
\hline $\begin{array}{l}\text { Net sediment transport (flood - } \\
\text { ebb): Export from the mouth } \\
\text { (intensity and extending) }\end{array}$ & $\begin{array}{l}\text { Increase of sediment } \\
\text { import in length up } \\
\text { to Ems-km } 35 \text { with } \\
800 \mathrm{t} / \mathrm{tide}\end{array}$ & $\begin{array}{l}\text { Increase of sediment } \\
\text { import in length up to Ems- } \\
\mathrm{km} 30 \text { with } 1.000 \mathrm{t} / \mathrm{tide}\end{array}$ & $\begin{array}{l}\text { Extension up to Ems-km } 20 \\
\text { with export } 10.000 \mathrm{t} / \text { tide } \\
\text { (Negative effect of polder } \\
\text { near the mouth) }\end{array}$ \\
\hline $\begin{array}{l}\text { Downstream shift of ETM: } \\
\text { intensity and distance of the } \\
\text { shift }\end{array}$ & $\begin{array}{l}\text { Downstream shift } \\
\text { with } 17 \mathrm{~km} \text {, } \\
\text { reduction to } 2.4 \mathrm{~g} / \mathrm{l}\end{array}$ & $\begin{array}{l}\text { Downstream shift with } 17 \\
\mathrm{~km} \text {, } \\
\text { reduction to } 2.1 \mathrm{~g} / \mathrm{l}\end{array}$ & $\begin{array}{l}\text { Upstream shift with } 5 \mathrm{~km} \text {, } \\
\text { but } \\
\text { reduction to } 2.5 \mathrm{~g} / \mathrm{l}\end{array}$ \\
\hline Restoration potential & low & low - moderate & low \\
\hline
\end{tabular}

The lengthening combined with the tidal polders near the mouth represented on short term a deficits with an upstream shift and only a slight decrease of the ETM. The most positive effect, which will result in a medium-term reduction of fine sediments in the lower Ems, is shown in a turn from net sediment import for the present situation to an export for this scenario was included by the lengthening and the tidal polders. Due to the negative effects of the mention upstream shift of the ETM the restoration potential of the analysed scenario was evaluated with low.

The lengthening of the Ems estuary combined with two downstream polders downstream, resulted in differing results, compared to the findings of previous studies. Thus a downstream shift of the ETM was examined by a 1d-approach of Schuttelaars \& De Jonge (2011) and reduction without a 
significant downstream shift of the ETM was examined by a 3d analysis by Rollenhagen (2011). The reasons for these different results are given by different assumption at the weir: here the weir was fully removed, which resulted in an extension of the tidal influence estuary length. This tidal influence without any ground sill induces on short term a mobilization of fine sediments upstream under reduced water depth and increase currents. This tidal water level additional evokes problems for the ground water and ecological aspects.

This lengthening shifts the ETM to upstream sections, but also separating the suspended sediment concentration into two separate diverging maximum, which was also revealed in the $1 \mathrm{~d}$ analysis (Schuttelaars \& De Jonge, 2011) for a very short lengthening of the Estuary. This is a pointer to an alterative combination of the lengthening by avoiding a fully removal of the weir, but supporting the positive effects by an additional retention of tidal volume upstream near the new ETM. The effects of tidal polders, upstream in scenario A2 and downstream in scenario B, were not analyzed herein, because details on their effect are published in Donner et al., 2012.

A powerful correlation between hydrodynamic changes, like flood dominance and sediment transport was not feasible. Only some slight connections between the net flow ratio and the suspended sediment concentration as well as the ratio of the gradients and the suspended sediment concentration were shown for some scenarios. An isolated interpretation of the restoration potential exclusively based on the hydrodynamic indicators, might deliver an insufficient priority variant.

Even if the here presented analysis on short-term does not deliver a final answer on the sustainability of restoration measures, it is essential to analyze shortcomings and the restoration effects, to reduce these deficits and to optimize the measures (scenarios), before a detailed and time consuming long-term analysis makes sense. Only for selected and optimized measures with a high restoration potential further analysis of long-term morphodynamic changes are feasible.

\section{ACKNOWLEDGMENTS}

The Joint Research Project of WWF Germany, BUND, NABU and University of Technology in Berlin called "Perspective revitalized Lower Ems" (Perspektive Lebendige Ems) is funded by the DBU (Deutsche Bundesstiftung Umwelt) and BINGO (Niedersächsische Bingo-Umweltstiftung). We would like to thank the project team for their support and the project review group with water authorities and international experts for the fruitful discussions.

\section{REFERENCES}

Burt, T.N. 1986. Field settling velocities of estuary muds. In Estuarine Cohesive Sediment Dynamics, A.J. Mehta. Ed, Springer-Verlag, pp. 126-150.

Donner, M., F. Ladage, and O. Stoschek. 2012. Impact and retention potential of tidal polders in an estuary with high suspended sediment concentrations. Conference Proceedings of ICHE, Florida.

Dronkers, J. 1986. Tidal Asymmetry and estuarine morphology. Netherlands Journal of Sea Research $202 / 3$, pp. $117-131$.

Herrling. G. and H.D. Niemeyer. 2007. Long-term Spatial Development of Habitats in the EmsDollard Estuary. HARBASINS Report.

Herrling. G. and H.D. Niemeyer. 2008. Hydro- and Morphological Pressures and Impacts. HARBASINS Report.

Herrling. G. 2008. Comparison of the hydrodynamic regime of 1937 and 2005 by applying mathematical modeling - natural versus anthropogenic changes in the Ems-Dollard estuary. Lower Saxony Water Management, Coastal Defence and Nature Conservation Agency, Coastal Research Station, Ems-Workshop in Emden, 14 an 15th February 2008.

Hoitink, A. J. F. Hoekstra P., and D. S. Van Maren. 2003. Flow asymmetry associated with astronomical tides: Implications for the residual transport of sediment, Journal of Geophysical Research, Vol. 108, No. C10, 3315, doi:10.1029/2002JC001539.

Jürges, J. and N. Winkel. 2003. Ein Beitrag zur Tidedynamik der Unterems, Bundesanstalt für Wasserbau, Dienststelle Hamburg, Referat Ästuarsysteme II, Mitteilungsblatt der Bundesanstalt für Wasserbau Nr. 86. 
Krone, R.B. 1962. Flume studies of the transport of sediment in estuarial processes. Hydraulic Engineering Laboratory and Sanitary Engineering Research Laboratory, Univ. of California, Berkley, California, Final Report.

Lang, G. 2003. Analyse von HN-Modell-Ergebnissen im Tidegebiet, Mitteilungsblatt der Bundesanstalt für Wasserbau Federal Waterways and Engineering Institute, Nr. 86.

Lange, J. 2006. Ausbau der Unterems - eine Chronik der Maßnahmen seit 1984 mit einer Bewertung der Umweltfolgen, WWF Germany.

Li, Z.H., Nguyen, K.D., Brun-Cottan, J.C. and J.M. Martin. 1994. Numerical simulation of the turbidity maximum transport in the Gironde estuary, France, Oceanologica Acta.

Nguyen, H.H. and L.H.C. Chua 2010. A Simplified Physically-based Model for Estimating Effective Floc Density. J. Hydraulic Engineering, ASCE, DOI: 10.1061/ASCE HY.1943-7900.0000355.

Nguyen, H.H. 2012. Modelling the Transport of Fine Suspended Sediments, PhD-Thesis, Nanyang Technological University, Singapore.

NLWKN Aurich 2009. Emssperrwerk Gandersum Herbst - Probestau vom 27. bis zum 29.09.08 mit Überführung der CELEBRITY SOLSTICE von Papenburg nach Gandersum, Gewässerkundlicher Landesdienst.

Partheniades, E. 1965. Erosion and deposition of cohesive soils, Proceedings of the American Society of Civil Engineers ASCE, Volume 91 HY1, pp. 105-139.

Rollenhagen, K. 2011. Untersuchungen zur Minderung des Schlickeintrags in die Unterems Vergleich von Lösungsvarianten, presentation at the colloquium of the Federal Waterways and Engineering Institute, 22.09.2011, www.baw.de

Salomon, J. C. and G. P. Allen. 1983. Role sedimentologique de la mare dans les estuaires a fort marnage, Compagnie Français de Petroles, Notes and Memoires 18, pp.35-44.

Schuttelaars, H.M. and V. De Jonge. 2011. Influence of the length of an estuary on tidal motion and sediment trapping, unpublished.

Schweim, C. 2005. Modellierung und Prognose der Erosion feiner Sedimente, PhD-Thesis, RWTH Aachen.

Speer, P. E. and D. G. Aubrey. 1985. A study of non-linear tidal propagation in shallow inlet/estuarine systems: Part II-theory, Estuarine, Coastal and Shelf Science 21, pp. 207-224.

Talke, S. A. and H. E. De Swart. 2006. Hydrodynamics and Morphology in the Ems/Dollard Estuary: Review of Models, Measurements, Scientific Literature, and the Effects of Changing Conditions, University of Utrecht, IMAU Report \# R06-01.

Van de Kreeke, J. 1996. Net transport of fine sediment in a homogeneous tidal channel, in Mixing in Estuaries and Coastal Seas, Coastal Estuarine Stud., vol. 50, edited by C. Pattiaratchi, pp. 361373, AGU, Washington, D. C., doi:10.1029/CE050p0361.

Van Rijn, L. C. 2007. Manuel Sediment Transport Measurements in Rivers, Estuaries and Coastal Seas. Aqua Publications, Amsterdam.

Weilbeer, H. 2005. Numerical simulation and analyses of sediment transport processes in the EmsDollard Estuary with a three-dimensional model, Conference Proceedings, INTERCOH 2003.

Winterwerp, H. 1999. On the Dynamics of High-concentrated Mud Suspensions. PhD-Thesis, TU Delft.

Wurpts, A. and D. Oberrecht. 2012. A hydro-morphodynamic numerical study to reduce tidal asymmetry in the Ems Estuary, Germany, Conference Proceedings of the ICCE 2012, Santander, Spain.

Zanke, U. C. E. 1982. Grundlagen der Sedimentbewegung, Springer Verlag, Berlin Heidelberg. 